Hazuchova, N., Antosova, I., \& Stavkova, J. (2020). Food Wastage as a Display of Consumer Behaviour.

Journal of Competitiveness, 12(2), 51-66 https://doi.org/10.7441/joc.2020.02.04

\title{
FOOD WASTAGE AS A DISPLAY OF CONSUMER BEHAVIOUR
}

\author{
- Nada Hazuchova, Irena Antosova, Jana Stavkova
}

\begin{abstract}
The article deals with consumer behavior in terms of food and its wastage. The main aim is to identify consumer behavior in relation to food consumption and food waste in the households in the Czech Republic as an effect of healthy competitive environment. Food consumption and its wastage is analyzed in terms of quantity and food expenditure in general as well as with the use of primary data from the Household Budget Survey. According to a household diary survey, the highest wastage is of cereal and dairy products, with the lowest being meat.

The consumption and quantity of wasted food are significant in relation to price. The data obtained during daily monitoring of wasted food in September 2018 are used to test the impact of the household identification characteristics on the quantity of wasted food along with the types. A logit regression is used to estimate the anticipated quantity of wasted food according to individual kinds of food and in relation to household identification characteristics. The age, education and economic activity of consumers have a significant effect on the quantity of wasted food. In addition, the results show that the people who waste the most are over 65 years of age, with the lowest wastage connected with university graduates.
\end{abstract}

Keywords: wastage, household consumption, food, competitiveness, factor, expenditure, income JEL Classification: D12, I30

Received: September, 2019

1st Revision: January, 2020

Accepted: May, 2020

\section{INTRODUCTION}

The issue of wastage is above all a moral question. People living in certain parts of the world suffer from lack of food and the uncertainty of whether they will have enough to eat tomorrow, and on the other hand, there are people who take their food for granted every day without having to think more deeply about this subject. The latter group do not seem to realize the value of food and that food wastage also has a further impact on the problems of the world today such as maintaining life on earth and a healthy environment (FAO, 2013). According to the Food and Agriculture Organization (FAO, 2013), about one-third of food is wasted in terms of the purpose for which it is produced. This amounts to about 1.3 billion tons of production p.a. This quantity of production which does not serve its purpose becomes waste and leads to problems connected with its disposal. Food wastage is becoming a subject of interest of many groups 
including agriculturists, environmentalists and technologists among others, as it is an ethical and social problem in developed societies. However, there is a serious lack of knowledge of food losses in the entire food chain. There has been more success in the identification and removal of losses technologically connected with production and processing (Parfitt et al., 2010), but less so in losses connected with distribution and sale (Monier et al., 2010; European Parliament, 2012) and the least success is in recognizing the reasons for household food wastage.

\section{THEORETICAL BACKGROUND}

Consumer behavior is affected by many factors, whereas tracing the effects and their interactions among them is problematic (Fischer, 2015). Cultural effects can be followed (Menzel \& D'Aluisio, 2008) with the goal of creating the foundation of an individual's behavior, which is frequently genetically embedded. The diverse qualities are difficult to quantify, not just among countries, but also within countries. The values that play an important role in consumer behavior have a cultural and ethnic basis (Cova et al., 2007). The role of these values in consumer behavior has been overlooked in empirical research, but on a theoretical basis, effects have been presented regarding the awareness of environmental and food security, together with values and moral thinking (Bamberg, 2003). The consumer's surroundings play a significant role in lifestyle choices, especially for families with consumers of younger ages. In addition, the surroundings with which a consumer comes in contact with play a similar role (friends, colleagues, etc.) (Kunzová \& Hrubá, 2013).

Among the factors affecting the origin of food waste, demographic factors, household size, and economic activity can be delineated, as well as, last but not least, the price of food that households buy. Demographic factors such as age or gender are usually crucial in all areas of consumer behavior (Mokrysz, 2016) and should be taken into account when designing consumer education campaigns focused on changing behavior (Filipová et al., 2017). According to Talia et al. (2019), the size of the household plays a fundamental role as well as the gender and education of household consumers. Single-person households generate more food waste than other types of households, with higher-income households and households in cities also found to waste more (Tokareva \& Eglite, 2017). Filipová et al. (2017) also state that consumers from higher-income households waste more as well as younger consumers and economically active consumers, while pensioners waste less than other groups. Ilakovac et al. (2020) add that the age of respondents positively affected the prevention of waste, while the income level and the number of children under the age of 18 in the household had an adverse impact.

The income situation of households also affects consumer behavior. It is said that the influence of emotions on consumer decision-making is significant, but the consumer's actions are still finally decided by what is in his/her wallet (Achar et al., 2016). The income situation of households is one of the main indicators of their living conditions and living standards. When a household has an income below the poverty level it is called a low-income household living at risk of poverty (Halleröd \& Larsson, 2008). Higher-income households waste more than the low-income households (Filipová et al., 2017). On the other hand, Porpino et al. (2015) add that a low-income household also wastes, e.g. because of the lack of planning or inability to store food properly. 
Priefer et al. (2013) state that with the growth of prosperity, there is also a growing trend of food wastage. Household food wastage can be expressed as the function of the price of raw food and household disposable income (Lusk \& Elison, 2017). Priefer et al. (2013) add that the trend of the decline in food expenditure is also causing the loss of respect for food in society. According to a Dutch study (Dooren et al., 2019), household waste amounts to 30.4 kilograms per person per year, with the greatest wastage of households on bakery products ( $22 \%$ of wasted food), then dairy products $(17 \%)$, vegetables $(14 \%)$, fruits $(12 \%)$ and the least on meat $(7 \%$ of wasted food) This sequence may be caused by the price of certain foods. A Croatian study states that households produce 75 kilograms of food waste per capita per year on average and almost half of the total wasted food consists of fruits (23\%) and vegetables (23\%) (Ilakovac, 2020). Fruits and vegetables are the most wasted types of food also in Great Britain, with almost 2 million tons of fresh vegetables and salads thrown away per year (Quested, 2011).

In economically advanced economies where most households do not face serious poverty problems, including the European Union, the tendency to waste food is higher. Because of this, food waste issues occupy top priority in the EU agenda (Ionut-Cosmin et al., 2019). The causes can be identified on the supply side in the food market. Companies and consumers are part of the present economic system and these mutually interact, with entities on the supply side doing their best to meet the needs of the demand side, i.e. households. The competitiveness of food supply entities contributes to an increase in food waste, as they compete with each other for better household satisfaction. More food is pushed onto households than they really need because of the competitiveness in the market, a situation that leads to food waste. Much of the food waste that comes from high-income or developed countries is caused by marketing practices (Calvo-Porral et al., 2017). Economic competition takes place in full force among food business entities, with food-related enterprises increasingly offering products with labels such as 'quality', 'green', 'ethical' and 'sustainability' to justify high premiums for their products (Arthur \& Yamoah, 2019).

Individualization is brought into conjunction with consumption. In today's economically developed countries, consumers demonstrate or compensate for their position in society by higher consumption, with the result of higher demands for material household amenities and food security (Krautová \& Librová, 2009). Quested \& Murphy (2014) state that people living alone throw away by half more than do people living in households with a greater number of members, who know how to economize better.

Five major categories of food waste causes are purchasing, over-preparation, caring for a pet, avoidance of leftovers and inappropriate food conservation. Several subcategories were found, e.g. impulse buying, lack of planning and preference for large packages (Porpino et al., 2015). Attitudes of consumers toward to food waste are different, some of them are aware of environmental problems related to food waste but some consumers agree that some food waste is necessary to ensure meals taste fresh (Qi \& Roe, 2016). Zhang et al. (2018) identify two major drives of household food waste: household size and income.

The individual consumer behavior is one of factors affecting the quality of the environment. Therefore, environmental effects are part of consumer behavior analyses including food wastage. Food waste leads to environmental and social awareness. The environmental impacts for every single product are different, for example bread and confectionery makes the highest impact 
according to both carbon (CO2) and monetary impact, meat and dairy makes the second highest impact on the environment (Dreyer et al., 2019). Food waste and CO2 emissions are increasing. The reduction of these issues can be achieved through improvements in consumer behavior. Priority should be given to the strategies that can increase people's awareness of food waste induced problems and then to reduce carbon emissions and make sustainable environment (Zhang et al., 2018).

\section{RESEARCH OBJECTIVE, METHODOLOGY AND DATA}

The aim of the paper is to identify consumer behavior of households in the area of food consumption and waste in economically advanced countries where a healthy competitive environment enables households to meet their material and intangible needs. To find out the size of food consumption but also the amount and structure of food not consumed (wasted) are basic necessary variables for the knowledge of consumer behavior according to different identification factors of households. Using the ordinal logistic regression, it is possible to estimate the expected behavior of households and to find ways of dealing with the negative externalities of production and consumption.

Many studies, such as Dooren et al. (2019) or Ilakovic et al. (2020), state that only a consumer survey is not enough for detailed revelation of wasted food in households and propose advanced methods of sorting household waste or keeping records in food waste diaries. As Quested et al. (2011) state, food waste diaries are one of the best ways of obtaining information how much food is wasted and also the reasons why food is thrown away. Because of these reasons, this paper is based on food waste diaries in households and on objective statistics the Household Budget Survey.

The Household Budget Survey (HBS) observes the management of households and provides information about the level of their expenditure and structure of consumption. The HBS is based on income, household composition, economic activity and other attributes. The HBS follows the segmentation according to Individual Consumption Classification which was created as part of transformation of the classification system as the Czech version of the COICOP international standard. Households are selected for the HBS by an intentional quota selection. The basic selection characteristic is a category of households derived from economic activity and the working position of the head of the household. Among other quota characteristics, there are the household cash income, household composition depending on the number of children and adults, size of municipality and type of a house (ČSÚ, 2019). In 2016, 1,538 Czech households took part in the survey.

The primary data are entries made in the diary survey on the quantity and type of composition of wasted food obtained by daily monitoring (weighing) in households stating their identification characteristics and the person being head of the household. The survey was organized by the authors of the paper. The number $n=100$ of the diary is the number of the households involved that were willing to make daily entries of the wasted kinds of food. The structure of the sample of the households involved corresponds in structure to the quota sample by age, economic status, the highest attained education, income situation and size of a city/village. The findings from this 
survey can be generalized thanks to the quota sample. The households weighed discarded food daily and recorded the amount of wasted food in diaries as for different types of food per month (September 2018).

During the data processing and calculations of the characteristics, this number could not always be maintained given that the respondents did not fill in some of the data. For descriptive statistics, the number of data $(n=100)$ is sufficient. However, in more advanced analyses due to the missing responses, these diaries were excluded from the processing. The data are used to follow the conclusive effect of the identification characteristics of households on food wastage as for individual kinds of food using the Mann-Whitney U test and the Kruskal-Wallis test. The Kruskal-Wallis test is used because of the fact that normality is not confirmed in the data. The ordinal logistic regression is used to estimate the anticipated behavior of categories of consumers created by alternative identification characteristics.

The ordinal logistic regression used variables of the quantity of wasted food, gender, age, economic activity and disposable income of a household. The ordinal logistic regression model is based on cumulative logits in the form 1 :

$\ln \frac{F_{j}}{1-F_{j}}=\ln \frac{P\left(Y \leq y_{j}\right)}{P\left(Y>y_{j}\right)}=\ln \frac{\pi_{0}+\pi_{1}+\cdots+\pi_{j}}{\pi_{j+1}+\pi_{j+2}+\cdots+\pi_{s-1}}, j=0,1 \ldots, s-2$

Then the regression function using the cumulative logit has the following form 2:

$\ln \frac{F_{j}}{1-F_{j}}=x^{\prime} \beta_{j,} j=0,1 \ldots, s-2$.

The methods mentioned applied to diary survey data will lead to determination of the anticipated behavior of typical consumers according to their identification characteristics. It would not be possible to propose arrangements and campaigns leading to a change in consumer behavior and a decrease in the volume of food wastage without the identification of typical consumers.

The hypotheses stated are listed in the following Table 1. The software used for the calculations from above, i.e. hypothesis verification by Mann-Whitney U Test and Kruskal-Wallis Test and the calculation of the regression model, is Statistica by Statsoft (version 12).

Tab. 1 - Hypotheses. Source: own research

\begin{tabular}{|l|l|l|}
\hline Hypothesis $\mathrm{H}_{0}$ & Hypothesis $\mathrm{H}_{1}$ & Source \\
\hline $\begin{array}{l}\text { The distribution of Wastage is } \\
\text { the same across categories of } \\
\text { Gender. }\end{array}$ & $\begin{array}{l}\text { The distribution of Wastage is not the } \\
\text { same across categories of Gender. }\end{array}$ & Mokrysz, 2016 \\
\hline $\begin{array}{l}\text { The distribution of Wastage is } \\
\text { the same across categories of } \\
\text { Age. }\end{array}$ & $\begin{array}{l}\text { The distribution of Wastage is not the } \\
\text { same across categories of Age. }\end{array}$ & Mokrysz, 2016 \\
\hline $\begin{array}{l}\text { The distribution of Wastage is } \\
\text { the same across categories of } \\
\text { Education. }\end{array}$ & $\begin{array}{l}\text { The distribution of Wastage is not the } \\
\text { same across categories of Education. }\end{array}$ & Talia et al., 2019 \\
\hline
\end{tabular}




\begin{tabular}{|l|l|l|}
\hline $\begin{array}{l}\text { The distribution of Wastage is } \\
\text { the same across categories of } \\
\text { Economic Activity. }\end{array}$ & $\begin{array}{l}\text { The distribution of Wastage is not the } \\
\text { same across categories of Economic } \\
\text { Activity. }\end{array}$ & Talia et al., 2019 \\
\hline $\begin{array}{l}\text { The distribution of Wastage is } \\
\text { the same across categories of } \\
\text { With Whom Lives. }\end{array}$ & $\begin{array}{l}\text { The distribution of Wastage is not the } \\
\text { same across categories of With Whom } \\
\text { Lives. }\end{array}$ & Zhang et al., 2018 \\
\hline $\begin{array}{l}\text { The distribution of Wastage is } \\
\text { the same across categories of } \\
\text { Number of Children under 18. }\end{array}$ & $\begin{array}{l}\text { The distribution of Wastage is not the } \\
\text { same across categories of Number of } \\
\text { Children under 18. }\end{array}$ & $\begin{array}{l}\text { Ilakovac et al., } \\
2020\end{array}$ \\
\hline
\end{tabular}

\section{RESULTS AND DISCUSSION}

When analysing the relation between food waste and household income levels, we came to conclusions consistent with the authors cited above (Achar et al., 2016; Tokareva \& Eglite, 2017) who agreed on the fact that household income is one of determining factors of the amount of the total food consumption including wasted food. The results of our analyses based on the HBS data from the latest year 2016 confirm that.

Tab. 2 - The share of expenditure on income in income deciles, year 2016. Source: HBS, 2019; own research

\begin{tabular}{|l|l|l|l|l|l|l|l|l|l|}
\hline Dec. 1 & Dec. 2 & Dec. 3 & Dec. 4 & Dec. 5 & Dec. 6 & Dec. 7 & Dec. 8 & Dec. 9 & Dec. 10 \\
\hline $98 \%$ & $98 \%$ & $92 \%$ & $89 \%$ & $88 \%$ & $90 \%$ & $81 \%$ & $80 \%$ & $79 \%$ & $69 \%$ \\
\hline
\end{tabular}

The distribution of income and expenditure components in individual deciles (Table 2) shows that income outweighs expenditure in all the deciles. It is worth noting that the first two income deciles, i.e. $20 \%$ of households, dispose of income that are equal to expenditure, i.e. these households must very carefully consider which needs to satisfy by what expenditure, eventually how to earn money to satisfy further needs. In view of low income households from the lowest income deciles, they are forced to change the structure of their consumption which is also seen in the quality and living standard.

\section{Food consumption and expenditure}

From the results of the COICOP survey about the structure of household expenditures of EU countries including the Czech Republic, it is clear that food expenditures can be characterized by a decrease of the share of food expenditure in total household expenditure. It can be caused by the amount of the total food consumed in households, the change of the structure of consumed food, an increased share of food consumed away from home, the change of life style, the change of household character and the change of their members, etc. (Talia et al., 2019). The authors Stancu et al. (2016) see the reason for wasted food in routine behavior, when the absence of planning of food purchase as needed and spontaneous shopping are typical.

Food consumption in individual European countries including the Czech Republic in recent years can be characterised by a fall in the share of expenditure on food out of total household 
expenditure, determined by the level of the total volume of food consumption, change in the structure of food and an increased share of food consumed outside the home.

Figure 1 shows food consumption and food expenditure as for to individual kinds expressed by the average per household. The average household expenditure on food is 166 EUR a month. On the other hand, households in the first income decile can afford food expenditure of a total of EUR 62 a month. It is worth mentioning that despite food expenditure in the first decile being about a third, consumption is about half. This indicates a decreased living standard of these low-income households. Low income households can afford only $5 \mathrm{~kg}$ of meat per month, which is less than half of average meat consumption.

The mutual comparison of expenditure and consumption of various kinds of food is presented in Figure 1 and 2. They contain the effect of the price of individual kinds of food on their consumption. An example can be the consumption of meat which in its natural form consists of only $13 \%$ of consumption, but expressed in money, monthly meat expenditure is $30 \%$ (i.e. EUR 50 per household). The opposite ratio is in milk and dairy products, in natural units of consumption, it is $42 \%$, the expenditure component in Euros is $19 \%$. This confirms that demand and consumption of food products are affected by their consumer price to a considerable extent. It is not seen in total food consumption, but is decided by which product and in what quality it is selected by the consumer, or which substitutes can replace it. The chosen example of meat consumption and meat products shows that meat will be wasted less due to its higher price and in contrast with dairy products the consumer's behavior will be higher wastage because of their lower price.

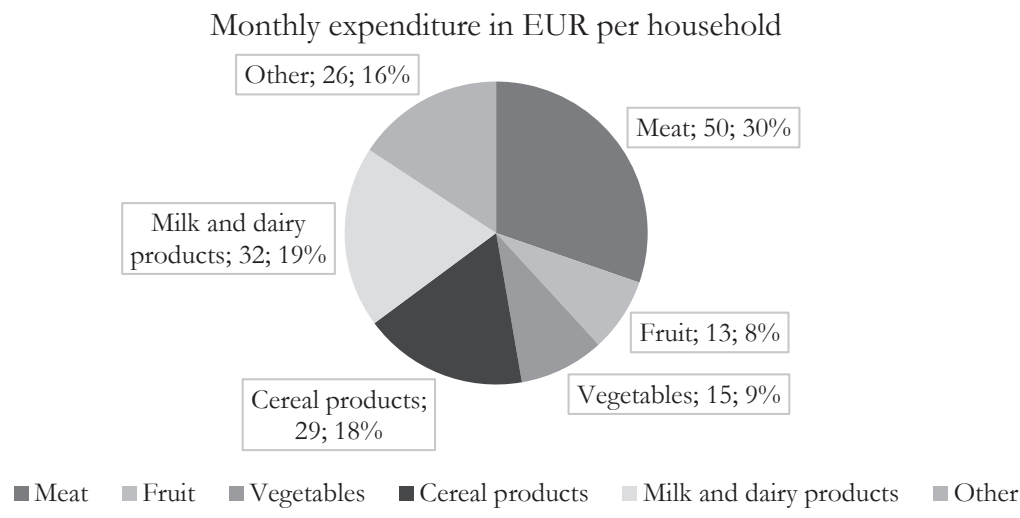

Fig. 1 - Household food expenditure. Source: HBS, 2016; own research 
Monthly consumption in MU in kg per household

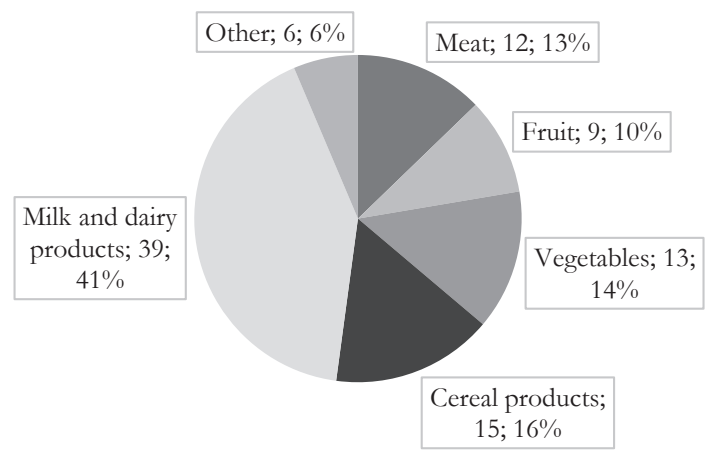

$\square$ Meat $\square$ Fruit $\square$ Vegetables $\square$ Cereal products $\square$ Milk and dairy products $\square$ Other

Fig. 2 - Household food consumption. Source: HBS, 2016; own research

Data processing from daily entries on food wastage in households, their quantity and structure

The results of diary survey made in 100 households are stated in Table 3 . The results can be considered to be valuable because households data are recorded daily for one month. The outcomes correspond to the results gained in the HBS database.

As for the wasted food (Table 3), meat and meat products are in last place which may be due to their highest price per consumption unit. Households most often waste cereal products and bakery products for the reason of their short durability. Wasted kinds of food derived from daily entries of households are affected by price and the method of their consumption. In contrast, expenditure on individual kinds of food shows an indirect relationship between consumption and price.

Tab. 3 - Monthly wasted food as per category. Source: own research

\begin{tabular}{|l|l|}
\hline Category & Wastage per household (in g) \\
\hline Meat and meat products & 31 \\
\hline Fruit & 47 \\
\hline Vegetables & 42 \\
\hline Cereal products & 58 \\
\hline Dairy products and cheese & 56 \\
\hline Ready meals (prepared at home) & 22 \\
\hline Other & 65 \\
\hline Total & 321 \\
\hline
\end{tabular}

The polemic with data about the whole amount of wasted food in households is very demanding because a unified definition of the category of food waste does not exist and the absence of unified methodology for monitoring the amount of wasted food occurs (Hazuchová et al., 2019). For that reason, any comparison between different countries and setting limits is problematic (Stenmarck et al., 2016). 
The results of the household diary survey show that cereal products $(18 \%)$ are wasted the most, then dairy products (17\%), fruit (15\%) and vegetables (13\%). This order corresponds to the study of Dooren et al. (2019). Compared to Croatian (Ilakovac et al., 2020) and British study (Quested et al., 2011) where fruit and vegetables are on the first places of wasted food, the order in Czech households is slightly different.

One third of food produced for human consumption is unnecessarily lost or wasted according to Food Agriculture Organization (2011). This amounts to about 1.3 billion tonnes per year. It should be noted that there is a number of estimates of the amount of food waste with different probabilities of approaching reality. In addition to keeping a diary on the structure and quantity of food thrown away in individual households or sorting and weighing the food waste in landfills for food estimation, it is possible to use statistics models in connection to population metabolism and body weight or as a percentage of total calories consumed, others as a percentage of total food consumed. For example, Monier et al. (2011) have estimated the average production of food rubbish as 179 kilograms per household per year (76 kg per capita) and Gillick \& Quested (2018) as $108 \mathrm{~kg}$ per capita per year in the UK.

The above-mentioned problems related to food waste quantification relate to households (final consumers who are considered to be the main producers of food rubbish).

\section{The impact of household identification factors on food wastage}

Even after removing extreme and remote values, we did not reach the normal data distribution. Thus, non-parametric tests were used to analyse the conclusive effect of the identification characterstics on the quantity of wasted food. These are robust against not meeting normal data distribution and also against extreme values.

The Mann-Whitney $\mathrm{U}$ test was chosen for an independent variable with two variants and the Kruskal-Wallis test was used for an independent variable for more than two variants. If the signficance is less than 0.05 , there is a statistically significant difference at least between one pair of variants of the independent variable.

Tab. 4 - The impact of identification characteristics of a person as head of the household on wastage. Source: own research

\begin{tabular}{|l|l|l|l|}
\hline Null Hypothesis & Test & Sig. & Decision \\
\hline $\begin{array}{l}\text { The distribution of Wastage is the } \\
\text { same across categories of Gender. }\end{array}$ & $\begin{array}{l}\text { Independent - Samples } \\
\text { Mann-Whitney U Test }\end{array}$ & 0.328 & $\begin{array}{l}\text { Retain the null } \\
\text { hypothesis. }\end{array}$ \\
\hline $\begin{array}{l}\text { The distribution of Wastage is the } \\
\text { same across categories of Age. }\end{array}$ & $\begin{array}{l}\text { Independent - Samples } \\
\text { Kruskal-Wallis Test }\end{array}$ & 0.000 & $\begin{array}{l}\text { Reject the null } \\
\text { hypothesis. }\end{array}$ \\
\hline $\begin{array}{l}\text { The distribution of Wastage is the } \\
\text { same across categories of Education. }\end{array}$ & $\begin{array}{l}\text { Independent - Samples } \\
\text { Kruskal-Wallis Test }\end{array}$ & 0.006 & $\begin{array}{l}\text { Reject the null } \\
\text { hypothesis. }\end{array}$ \\
\hline $\begin{array}{l}\text { The distribution of Wastage is the } \\
\text { same across categories of Economic } \\
\text { Activity. }\end{array}$ & $\begin{array}{l}\text { Independent - Samples } \\
\text { Kruskal-Wallis Test }\end{array}$ & 0.000 & $\begin{array}{l}\text { Reject the null } \\
\text { hypothesis. }\end{array}$ \\
\hline
\end{tabular}




\begin{tabular}{|l|l|l|l|}
\hline $\begin{array}{l}\text { The distribution of Wastage is the } \\
\text { same across categories of With } \\
\text { Whom Lives. }\end{array}$ & $\begin{array}{l}\text { Independent - Samples } \\
\text { Kruskal-Wallis Test }\end{array}$ & 0.073 & $\begin{array}{l}\text { Retain the null } \\
\text { hypothesis. }\end{array}$ \\
\hline $\begin{array}{l}\text { The distribution of Wastage is the } \\
\text { same across categories of Number of } \\
\text { Children under } 18 .\end{array}$ & $\begin{array}{l}\text { Independent - Samples } \\
\text { Kruskal-Wallis Test }\end{array}$ & 0.084 & $\begin{array}{l}\text { Retain the null } \\
\text { hypothesis. }\end{array}$ \\
\hline
\end{tabular}

The results of the tests (Table 4) show that the household gender and structure formation has no effect on the quantity of wasted food. The same applies to the number of children characteristic (but not the total number of household members). In contrast, education, economic activity and age have a conclusive effect on the quantity of wasted food. The conclusive effect indicates a large difference in the quantity of wasted food between the levels of the monitored characteristics.

Older people are more economical in their behavior because of their life experience, i.e. they show respect for nature and the fruits thereof. When the wastage for category 65 achieves higher values, this can be described as so-called eco-wastage, which means that the wasted food has further use (animal feed, compost) and is not such a burden on the environment and does not increase disposal costs. Pensioners state that the reason for their wastage is the size of packaging and the subsequent spoiling of food caused by a longer period of storage. Education becomes important and is displayed in the form of healthy lifestyle and nature protection. Economic activity is displayed in both directions, i.e. in the negative sense in connection with the household income situation it allows some categories of food waste in greater quantity, and on the contrary, in connection with a higher education level in a healthy lifestyle without wastage.

The significance has been tested in the regressive model with all analyzed variables which have an effect on food wastage - Table 6 . Table 5 shows the results of proportional odds assumption, according to which an ordinal logistic regression is a suitable method to describe the variable explained.

Tab. 5 - Proportional odds assumption. Source: HBS, 2019; own research

\begin{tabular}{|l|l|l|l|l|}
\hline \multicolumn{5}{|l|}{ Test of Parallel Linesa } \\
\hline Model & -2 Log Likelihood & Chi-Square & df & Sig. \\
\hline Null Hypothesis & 117,880 & & & \\
\hline General & $74.210 \mathrm{~b}$ & $43.671 \mathrm{c}$ & 33 & .101 \\
\hline
\end{tabular}

The null hypothesis states that the location parameters (slope coefficients) are the same across response categories. 
Tab. 6 - Parameter estimates of the regression model. Source: HBS, 2019; own research

\begin{tabular}{|c|c|c|c|c|c|c|c|c|}
\hline \multicolumn{9}{|c|}{ Parameter Estimates } \\
\hline & & \multirow[t]{2}{*}{$\begin{array}{l}\text { Esti- } \\
\text { mate }\end{array}$} & \multirow[t]{2}{*}{$\begin{array}{l}\text { Std. Er- } \\
\text { ror }\end{array}$} & \multirow[t]{2}{*}{ Wald } & \multirow[t]{2}{*}{$\mathrm{df}$} & \multirow[t]{2}{*}{ Sig. } & \multicolumn{2}{|c|}{$\begin{array}{l}95 \% \text { Confidence } \\
\text { Interval }\end{array}$} \\
\hline & & & & & & & $\begin{array}{l}\text { Lower } \\
\text { Bound }\end{array}$ & $\begin{array}{l}\text { Upper } \\
\text { Bound }\end{array}$ \\
\hline \multirow{4}{*}{ 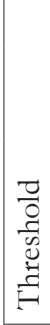 } & $\mathrm{c} \mathrm{g}$ & -1.611 & 1.887 & .729 & 1 & .393 & -5.309 & 2.087 \\
\hline & $\begin{array}{l}\text { Wastage 4001- } \\
6000 \mathrm{~g}\end{array}$ & -.079 & 1.894 & .002 & 1 & .967 & -3.792 & 3.633 \\
\hline & $\begin{array}{l}\text { Wastage } 6001 \text { - } \\
8000 \mathrm{~g}\end{array}$ & 1.158 & 1.902 & .371 & 1 & .543 & -2.570 & 4.886 \\
\hline & $\begin{array}{l}\text { Wastage of more } \\
\text { than } 8000 \mathrm{~g}\end{array}$ & 1.759 & 1.903 & .854 & 1 & .355 & -1.971 & 5.488 \\
\hline \multirow{15}{*}{ 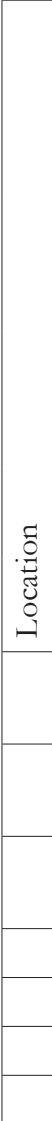 } & Age $18-29$ & -2.655 & 1.670 & 2.527 & 1 & .112 & -5.927 & .618 \\
\hline & Age 30-49 & -3.221 & 1.630 & 3.906 & 1 & .048 & -6.416 & -.027 \\
\hline & Age 50-64 & -1.326 & 1.566 & .717 & 1 & .397 & -4.395 & 1.743 \\
\hline & Age 65+ & $0^{a}$ & . & . & 0 & . & . & . \\
\hline & $\begin{array}{l}\text { Secondary educa- } \\
\text { tion without the } \\
\text { maturita exam }\end{array}$ & 2.121 & 1.160 & 3.344 & 1 & .067 & -.152 & 4.394 \\
\hline & $\begin{array}{l}\text { Secondary educa- } \\
\text { tion with the } \\
\text { maturita exam }\end{array}$ & 1.597 & .790 & 4.090 & 1 & .043 & .049 & 3.145 \\
\hline & $\begin{array}{l}\text { Higher vocational } \\
\text { education }\end{array}$ & 2.732 & 1.439 & 3.604 & 1 & .058 & -.089 & 5.554 \\
\hline & $\begin{array}{l}\text { University educa- } \\
\text { tion }\end{array}$ & $0^{a}$ & . & . & 0 & . & . & . \\
\hline & $\begin{array}{l}\text { Employee's eco- } \\
\text { nomic activity }\end{array}$ & 3.026 & .732 & 17.091 & 1 & .000 & 1.591 & 4.461 \\
\hline & $\begin{array}{l}\text { Pensioner's eco- } \\
\text { nomic activity }\end{array}$ & .026 & 1.684 & .000 & 1 & .988 & -3.275 & 3.327 \\
\hline & $\begin{array}{l}\text { Student's eco- } \\
\text { nomic activity }\end{array}$ & $0 \mathrm{a}$ & . & . & 0 & . & . & . \\
\hline & Low income & -2.829 & 1.375 & 4.235 & 1 & .040 & -5.523 & -.135 \\
\hline & Average income & -1.837 & .982 & 3.500 & 1 & .061 & -3.761 & .087 \\
\hline & Suitable income & -.741 & .909 & .665 & 1 & .415 & -2.523 & 1.041 \\
\hline & High income & $0^{a}$ & . & . & 0 & . & . & . \\
\hline
\end{tabular}

Link function: Logit.

a. This parameter is set to zero because it is redundant. 


\section{The parameter estimates show that:}

The people who waste the most are aged 65 and more. In all other categories, there is the lesser chance of belonging to a category of a higher quantity of food wastage. Only the $30-49$ year category differs from the 65+ category. Students waste less compared to pensioners and the employed. Employees have an almost 21 times greater chance of belonging to a category of a higher quantity of wastage (e3.026). Pensioners do not differ significantly from students in wastage. People with a university degree waste the least. All other categories as for the education level waste more. Secondary school graduates who have completed the maturita (a secondary school graduation exam in the Czech Republic with emphasis on preparation for university studies) have a 15 times greater chance of belonging to the category of a higher quantity of food wastage than university graduates (e2.732). As for income, the generally expected result is that the lower the income, the lower the chance of great wastage.

\section{CONCLUSION}

Consumption continues to increase, as does the number of unconsumed products in developed economies. The literature states that up to a third of the food produced is not consumed and is destined for disposal. Therefore, the motivations of consumer behavior must be recognized to determine an individual's needs and what influences his/her shopping habits. The results of the secondary data investigation (HBS) show that the determining factor for the size of consumption is a household's income situation. The average income exceeds the average expenditure, and households can satisfy their needs. However, the values of monthly household disposable income in deciles show that households of the first two income deciles correspond to expenditure and in the next deciles, these already exceed income over household expenditure. Households of the 3 rd - 6th decile are left with $10 \%$ of total income for savings or investments, $20 \%$ of the income of the 7 th -9 th decile serves this purpose, while it is as much as $32 \%$ for the last decile.

In 2016, Czech households spent an average of 4,219 CZK a month on food, but low-income households (1st decile) only spent 1,566 CZK a month. As a consequence, it changes the structure and quality of food resulting in the necessary decrease in expenditure.

The individualization of society affects total consumption. A series of further findings can be deduced when studying the factors affecting consumer behavior during purchase, in consumption, and with regard to the unconsumed quantity of food. For the group of single-member households, quantity discount offers may be financially advantageous, but their consumption is not and results in waste (Macková et al., 2019). The effect of price on total consumption of individual types of food can be demonstrated. Meat consumption and meat products in natural form only account for $13 \%$ of total food consumption; in terms of money, this is $30 \%$. The opposite is the situation concerning milk. In natural form milk and dairy products account for $42 \%$ of total consumption; in terms of money, this is $19 \%$. Food wastage in terms of quantity corresponds to consumption in natural form. The most wasted foods are dairy products, cereal products, fruit and vegetables. The least wasted is meat and meat products.

The primary data obtained from daily records about the quantity and structure of food wasted by households show a somewhat different sequence in the quantity of the types of food wasted. 
Households waste vegetables and fruit the most (this matches the data from international sources), then cereal products and the same results from sources (HBS), indicating that households waste meat and meat products the least.

The analysis of primary data involving the testing of the effect of household identification characteristics on the quantity of food wastage showed the effect of age, level of education and economic activity. The evidence of the effect of the level of identification characteristics of the person as the head of a household on the type of food wastage was verified by the Kruskal-Wallis test. An example is the identification characteristic of education and its effect on the wastage of bakery products, wastage of meat, milk and dairy products and ready-made food. On the contrary, a different level of education does not have an effect on fruit or vegetable wastage.

The use of the logit regression model makes it possible to estimate expected behavior in groups of respondents created according to the level of monitored identification characteristics. For example, secondary school students have a 15 times greater chance of being classed in the groups with a higher quantity of wastage than university students, and employees have as much as a 21 times greater chance of being classed in groups with a higher quantity of food wastage than students. These findings and the degrees of these likelihoods express the possibility of the effective impact on the given target group. Taking an active part in changes in consumer behavior in order to reduce the size of food wastage is determined by the fact that the issue of prevention and restriction of losses and food wastage has become a political agenda of the European Parliament (European Court of Auditors, 2016).

It must be stated that to deduce conclusions concerning the quantity of food wastage and its structure can be problematic. This has been shown by the investigation results (HBS x dailies) and the endeavor to make comparisons with the results of other authors, with various results from different authors an indicating this. We see the main reason for this in the absence of a universally applicable definition of food wastage as well as inconsistencies regarding the methodology for determining the quantity and structure of food wastage. The quantification of food wastage is provided by initial data connected with the society-wide need of effective measures for environmental protection. In turn, the results and conclusions expressed about consumer behavior, above all the effect of identification characteristics (education, income situation, age), can be used for the effective impact on change in consumer behavior, leading to a decrease in the volume of food wastage. Here there is a potential for further research in terms of developing techniques for the more in-depth recognition of behavior of consumers in satisfying their needs along with the changing opinions in society regarding to what degree the status of an individual depends on other values than the size of consumption.

Naturally, the diary survey method has some limitations. Measuring and weighing the amount of food thrown away and recording it into diaries is time consuming for research participants, which in our case why the number of respondents is not higher. Respondent awareness of their participation in research can also reduce the reported amount of food waste compared to what would take place under normal circumstances, indicating another limitation. 


\section{References}

1. Achar, C., So, J., Agrawal, N., \&Duhachek, A. (2016). What we feel and why we buy: the influence of emotions on consumer decision-making. Current Opinion in Psychology, 10 (1), 166-170. http://dx.doi.org/10.1016/j.copsyc.2016.01.009

2. Arthur, I. K., \& Yamoah, F. A. (2019). Understanding the role of environmental quality attributes in food-related rural enterprise competitiveness. Journal of Environmental Management, 247, 152-160. http://dx.doi.org/10.1016/j.jenvman.2019.06.093

3. Bamberg S. (2003). How does environmental concern influence specific environmentally related behaviors? A new answer to an old question. Journal of Environmental Psychology, 23 (1), 21-32. http://dx.doi.org/10.1016/S0272-4944(02)00078-6

4. Calvo-Porral, C., Medín, A. F., \& Losada-López, C. (2017). Can Marketing Help in Tackling Food Waste? Journal of Food Products Marketing, 23 (1), 42-60. http://dx.doi.org/10.1080/104544 46.2017.1244792

5. Cova B., Kozinets R., \& Shankar A. (2007). Consumer tribes. Amsterdam: ButterworthHeinemann.

6. Dreyer, H. C., Dukovska-Popovska, I., Yu, Q., \& Hedenstierna, C. P. (2019). A ranking method for prioritising retail store food waste based on monetary and environmental impacts. Journal of Cleaner Production, 210 (1), 505-517. http://dx.doi.org/10.1016/j.jclepro.2018.11.012

7. ČSÚ. (2019). HSB. Statistika rodinných účtů (SRÚ) - Metodika do roku 2016. Retrieved May 9 , 2019. https://www.czso.cz/csu/czso/statistika-rodinnych-uctu-metodika.

8. Dooren C., Janmaat O., Snoek J., \& Schrijnen M. (2019). Measuring food waste in Dutch households: A synthesis of three studies. Waste management, 94 (1), 153-164. http://dx.doi. org/10.1016/j.wasman.2019.05.025

9. European Court of Auditors. (2016). Special Report: Combating Food Waste: an opportunity for the EU to improve the resource-efficiency of the food supply chain. Luxembourg: Publications Office of the European Union.

10. European Parliament. (2012). How to avoid food wastage: strategies for a more efficient food chain in the EU, 2011/2175. Retrieved May 5, 2019. https://oeil.secure.europarl.europa.eu/ oeil/popups/ficheprocedure.do?lang=en\&reference=2011/2175(INI).

11. FAO. (2013). Food wastage footprint, summary report. Retrieved June 28, 2019. http://www. fao.org/3/i3347e/i3347e.pdf

12. Filipová, A., Mokrejšová, V., Šulc, Z., \& Zeman, J. (2017). Characteristics of food-wasting consumers in the Czech Republic. International Journal of Consumer Studies, 41(6), 714-722. http:// dx.doi.org/10.1111/ijcs.12384

13. Fischer, A. R. H. (2015). Consumer Behavior and Food Science. In G. W. Smithers (Ed.), Reference Module in Food Science Elsevier. https://doi.org/10.1016/B978-0-08-1005965.03335-7

14. Food Agriculture Organization. (2011). The state of the world's land and water resources for food and agriculture: managing systems at risk. New York, NY: Earthscan. ISBN 978-1-84971-326-9. 
15. Gillick, S., \& Quested, T. (2018). Household food waste: related data for 2007-2015. Final Report. WRAP. Retrieved January 30, 2020. http:/www.wrap.org.uk/sites/files/wrap/ Household $\% 20$ food $\% 20$ waste $\% 20$ restated $\% 20$ data $\% 202007-2015 \% 20$ FINAL.pdf

16. Halleröd, B., \& Larsson, D. (2008). Poverty, welfare problems and social exclusion. International Journal of Social Welfare, 17 (1), 15-25. http://dx.doi.org/10.1111/j.1468-2397.2007.00503.x

17. Hazuchová, N., Tuzová, M., Macková, M., \& Stávková, J. (2019). Household food waste behaviour: subjective and objective evidence. Potravinarstvo Slovak Journal of Food Sciences, 13 (1), 784-792. http://dx.doi.org/10.5219/1163

18. Ilakovac, B., Voca, N., Pezo, L., \& Cerjak, M. (2020). Quantification and determination of household food waste and its relation to sociodemographic characteristics in Croatia. Waste Management, 102 (1), 231-240. http://dx.doi.org/10.1016/j.wasman.2019.10.042

19. Ionut-Cosmin, G., Ionela-Iasmina, V., Roxana, M. A., \& Mihaela, B. I. (2019). Food Waste a Major Problem in the European Union. Agricultural Management, 21 (3), 65-75.

20. Krautová Z., \& Librová H. (2009). Spotřeba domácností a proces individualizace v environmentální perspektivě. Sociální studia, Brno: FSS MU, 6 (3), 31-55.

21. Kunzová, Š, \& Hrubá, D. (2013). Health and behaviour Part I - Lifestyle and disease. Hygiena, 58 (1), 23-28.

22. Lusk J. L., \& Ellison B. (2017). A note on modelling household food waste behaviour. Applied Economics Letters, 24 (16), 1199-1202. http://dx.doi.org/10.1080/13504851.2016.1265070

23. Menzel P., \& D’Aluiso F. (2008). What the world eats. Berkeley, Calif.: Tricycle Pres.

24. Mokrysz, S. (2016). Consumer Preferences and Behaviour on the Coffee Market in Poland. Forum Scientiae Oeconomia, 4 (4), 91-107.

25. Monier, V., Mudgal, S., Escalon, V., O’Connor, C., Gibon, T., Anderson G., \& Montoux, H. (2010). Preparatory Study on Food Waste Across EU 27. France: Bio Intelligence Service. Retrieved January 30, 2020. http://ec.europa.eu/environment/eussd/pdf/bio_foodwaste_ report.pdf.

26. Parfitt J., Barthel M., \& Macnaughton S. (2010). Food waste within food supply chains: quantification and potential for change to 2050. Philosophical Transactions of the Royal Society B, 365, 3065-3081. http://dx.doi.org/10.1098/rstb.2010.0126

27. Porpino, G., Parente, J., \& Wansink, B. (2015). Food waste paradox: antecedents of food disposal in low income households. International Journal of Consumer Studies, 39 (6), 619-629. http://dx.doi.org/10.1111/ijcs.12207

28. Priefer C., Jörissen J., \& Bräutigam K. R., (2013). Technology options for feeding 10 billion people Options for cutting food waste. Brusel: STOA.

29. Quested T. E., \& Murphy L. (2014). Final report: Household food and drink waste: A product focus. Wrap, Banbury, Oxon. Retrieved July 1, 2019, from http://www.wrap.org.uk/sites/files/ wrap/Product-focused $\% 20$ report $\% 20 v 5 \_3 . p d f$

30. Quested T. E., Parry, A. D., Easteal, S., \& Swannell, R. (2011). Food and drink waste from householdsin the UK. Nutrition Bulletin, 36 (4), 460-467. http://dx.doi.org/10.1111/j.14673010.2011.01924.x 
31. Qi, D., \& Roe, E. (2016). Household Food Waste: Multivariate Regression and Principal Components Analyses of Awareness and Attitudes among U.S. Consumers. PLoS ONE, 11 (7), 1-19. http://dx.doi.org/10.1371/journal.pone.0159250

32. Stancu, V., Haugaard, P., \& Lähteenmäki, L. (2016). Determinants of consumer food waste behaviour: Two routes to food waste. Appetite, 96 (1), 7-17. http://dx.doi.org/10.1016/j. appet.2015.08.025

33. Stenmarck, Å., Jensen, C., Quested, T., \& Moates, G. (2016). Estimates of European food waste levels. Report of the project FUSIONS (contract number: 311972) granted by the European Commission (FP7). Stockholm, Sweden: IVL Swedish Environmental Research Institute.

34. Talia E., Simeone M., \& Scarpato D. (2019). Consumer behaviour types in household food waste. Journal of Cleaner Production, 214 (1),166-172. http://dx.doi.org/10.1016/j. jclepro.2018.12.216

35. Tokareva, T., \& Eglite, A. (2017). Food Waste in Latvian Households: Amounts, Economic aspects. Economic Science for Rural Development Conference Proceedings, 46 (1), 213-219.

36. Zhang, H., Duan, H., Andric, J., Song, M., \& Yang, B. (2018). Characterization of household food waste and strategies for its reduction: A Shenzhen City case study. Waste Management, 78 (1), 426-433. http://dx.doi.org/10.1016/j.wasman.2018.06.010

\section{Contact information}

Ing. Mgr. Nada Haquchova, Ph.D.

Mendel University in Brno

Faculty of Business and Economics

Department of Marketing and Trade

Crech Republic

E-mail:nada.bazuchova@mendelu.cz.

ORCID:0000-0002-5693-9872

Ing. Irena Antosova

Mendel University in Brno

Faculty of Business and Economics

Department of Marketing and Trade

Czech Republic

E-mail:irena.antosova@mendelu.cr.

ORCID:0000-0002-4331-4187

prof. Ing. Jana Stavkova, CSc.

Mendel University in Brno

Faculty of Business and Economics

Department of Marketing and Trade

Czech Republic

E-mail:jana.stavkova@mendelu.cz.

ORCID: 0000-0002-0889-0218 